\author{
Dariusz Skalski ${ }^{1}$, Damian Kowalski ${ }^{1}$, Michat Tuz ${ }^{2}$ \\ ${ }^{1}$ Academy of Physical Education and Sport Jędrzej Śniadecki in Gdańsk \\ ${ }^{2}$ Naval Academy of Bohaterów Westerplatte in Gdynia
}

\title{
STATE SYSTEMS AND PATTERNS OF PHYSICAL CULTURE AND HEALTH SECURITY
}

The work deals with the discussion of the issue of relations between the economy and politics and school physical education over the centuries in selected European countries and in Poland, up to the time of the political transformation.

The aim of this work is to outline the relationship between the politics and economy of the state and physical education and health education.

The starting point for these considerations is kalokagatia and the intellectual categories of modern and contemporary spiritual culture defining rational thinking regarding the importance of physical culture and health education for society. In every country over the centuries, regardless of the political system of exercising power - politics and economy functioned in mutual relation with education, upbringing, including models of physical culture. The foundation of physical culture in each country is the school physical education system. The task of physical education methodology is to create a rational, structural model of putting the theory into practice. Physical culture as a social phenomenon stands out from others in that its influences concern man as a whole, concern both the body and its needs as well as personality.

To gain the aim the comparative analysis of physical culture and health education in democratic and totalitarian systems was held. The results of the analysis showed the asymmetry of issues between physical culture and health education in democratic and totalitarian systems in favor of the democratic system. In order to obtain the necessary information, the authors reached for rich materials and studies on totalitarian systems to get a picture of the subject.

The authors attempted to synthesize the place of physical culture against the background of health education in state systems in which emphasis was placed on man and his needs. The approach to physical activity as the basis of health and preparation for combat was also shown, which was believed to be the basis for maintaining peace.

Keyworlds: state systems, health education, physical culture, totalitarianism, physical education.

Даріуш Скальські, Даміан Ковальські, Міхал Туз

\section{ПОРІВНЯЛЬНИЙ АНАЛІЗ ПРИКЛАДІВ РЕАЛІЗАЦЇ̈ ДЕРЖАВНОЇ ПОЛІТИКИ У СФЕРІ ФІЗИЧНОЇ КУЛЬТУРИ ТА ОХОРОНИ ЗДОРОВ'Я}

У роботі розглянуто багатовікову еволюцію зв'язку між політичним та економічним станом справ у державі та фізичним вихованням у школах ряду країн Свропи, зокрема, у Польщі.

Метою роботи є дослідження взаємозв'язку між політичним устроєм держави та фізичним вихованням і здоров'язбережувальною освітою.

Відправною точкою аналізу є калокагатія та інтелектуальні категорії духовної культури та раціонального мислення, що підкреслюють важливість фізичного виховання і здоров'язбережувальної освіти для суспільства. Впродовж багатьог століть у кожній країні, незалежно від форми державного устрою, політика і економіка функціонували в тісному взаємозв'язку із освітою, зокрема, і фізичним вихованням. Наріжним каменем фізичного виховання у кожній державі $є$ шкільна освіта. Основним завданням методології фізичного виховання у школах $\epsilon$ створення раціональної структурної моделі реалізації теорії на практиці. Як соціальне явище, фізичне виховання чітко виокремлюються 3-поміж інших освітніх категоріїй, забезпечуючи вплив на становлення як фізичного так і духовного стану особистості.

Для досягнення поставленої мети було проведено порівняльний аналіз систем фізичного виховання і здоров'язбережувальної освіти в демократичних і тоталітарних державах. Результати вказують на велику різницю у кількості проведених досліджень на цю тему (у цьому аспекті держави 3 демократичним устроєм мають велику перевагу). Відтак, для повноцінного порівняння автори та отримання повноцінного уявлення, авторам довелося опрацювати велику кількість літератури про тоталітарні системи.

Автори здійснили спробу знайти місце фізичного виховання у системі здоров'язбережувальної освіти, в якій на першому місці стоїть особистість та ії потреби. Сформовано концепцію підходу до фізичної активності як запоруки здорового образу життя подібно до підготовки до війни як запоруки миру. 
Ключові слова: форма державного устрою, здоров'язбережувальна освіта, фізична культура, фізичне виховання, тоталітаризм.

\section{Introduction}

Over the centuries, the political and economic conditions of the countries have changed, which have created relationships with pedagogical thought, education and physical education, also as an educational system for young people in European and world countries. This essay discusses the issue of relations between the economy and politics and school physical education over the centuries in selected European countries and in Poland, up to the time of the political transformation. Thus, to a large extent I will refer to matters of education with which physical education is closely connected. Many researchers note that school physical education throughout history, from ancient times, has always been linked to the economy and politics of states. These, in turn, were not only about the strength of the state, but they defined social divisions and the system of values, they also determined the fate and life of people and entire societies. Paying attention to these issues is not only of historical importance. In view of the enormity of the material and issues, it will be a fragmentary approach, because it is impossible to discuss the whole issue in such a short work. These issues were, and is, the subject of interest of various scientific disciplines from history through social sciences, up to and including philosophy. To clarify the work, the meaning of the concepts contained in the subject should be clarified: kalokagatia, liberal democratic state, totalitarian systems, patterns of physical culture functioning in both systems, health education.

\section{Kalokagatia as an important context of modern European culture}

At this point, it should be mentioned that people have been training and exercising their body for thousands of years, with military, utilitarian and hedonistic considerations in mind. This was the case in ancient China, Babylonia, Egypt, the Aztec state and Europe ${ }^{1}$. In modern European culture, physical exercises have acquired a special meaning. Over time, included in school programs as physical education are an important factor in the physical development of children and adolescents. It is worth emphasizing the huge impact of ancient Roman and Greek civilizations, as well as the culture of Athens and its school system called „,paidea” (gr. Pais-children, upbringing, education of the child $)^{2}$. The purpose of paidea was to shape, educate a beautiful and wise man based on the highest ideals and the most perfect patterns, and its basic component were issues related to nobility, morality or

\footnotetext{
${ }^{1}$ Marrou H.I, Historia wychowania w Starożytności, Warszawa 1969, s. 32-35.

${ }^{2}$ Okoń W., Nowy słownik pedagogiczny, Wydawnictwo Akademickie Żak, Warszawa 2017, s. 41.
}

goodness of man, achieving versatile "perfection", harmoniously combining the qualities of the body and the spirit of a man called "kalokagatia" which was an educational inspiration for many European countries. Greek Kalokagatia means kalos kagathos literally beautiful and good. Beauty meant physical fitness and harmonious body composition. Good meant desirable moral, mental and artistic qualities. The whole was the ideal of comprehensive student development.

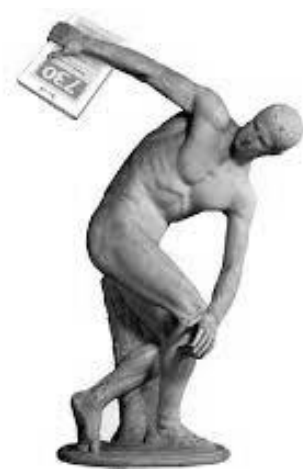

Fig. 1 - Illustration of a discobolus. Myron. Modern version.

(Source: $w w w$. google.com/search? client $=$ firefoxb $\&$ ei $=o A j$ 4W8HVNMOssgG1YPAAg\&qpaideia+grafika)

In short, it can be said that this system consisted of conducting education from 8 to 18 years of age in gymnasiums maintained by the state. Kalokagatia has become part of the broadly understood and admired Greek culture. Physical fitness was indispensable in the army and admired at the Olympic Games, this system of physical development provided Athens with economic and political development, security for the population. ${ }^{3}$ The history of the ethical issue of perfection originates from Plato, although it was only the stoics who included its concept in ethics, interpreting perfection as a harmony of man with nature, with himself, with reason. These two perfection coincided in the kalokagatia, which is a Doric and Ionian model of education, which is a model - due to its timeliness and positive fruits, it is also worth accepting in today's pedagogy, especially in its practical dimension.

Education without physical activity (so-called agon) was unthinkable in ancient Greeks. Today, the improvement of mind and spirit should go hand in hand with physical improvement for the benefit of children and young people. The Greeks were able to combine these three types of education (moral, intellectual, physical) in the notion and the ideal, which

\footnotetext{
${ }^{3}$ Ordyłowski M., Historia kultury fizycznej, Starożytność-

Oświecenie, Akademia Wychowania Fizycznego we Wrocławiu, Wrocław 1997, s. 80-83.
} 
is kalokagatia. In the sphere of physical education, they created his ideal. They wanted the body (like the spirit) to become perfectly beautiful. The fact is that kalokagatia was an educational inspiration not only for ancient countries, but also for modern education in Western European countries. The achievements of Greek and Roman thought abounded in not only practical but also theoretical achievements that were useful in the emerging economic conditions of Europe. Cultural and civilization changes, including educational ones, of the leading countries over the years were closely related. Physical education in all this provided the necessary physical fitness of young people, also fulfilled the educational purpose of bringing up new values for the needs of the state.

\section{Physical Culture in totalitarianism}

Totalitarianism - a political system in which the state controls and regulates all manifestations of citizens' lives. The rule of leadership is the official rule of the system. Power seeks total control, subordination and indoctrination of the individual in the spirit of the prevailing ideology. The features of this system are: extensive techniques of mass propaganda, one monopolistic party under the direction of a dictator, terrorist police control, full control over the armed forces, centralized control of the entire market, unification of control and its penetration into all areas of life. Education, like other areas of life, remained under full control of politicians ${ }^{4}$. An example is the concept of A. Hitler, B. Mussolini, and J. Stalin.

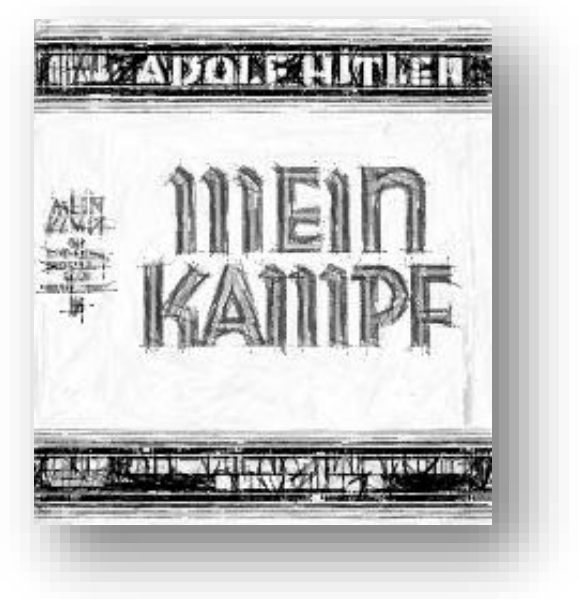

Fig. 2 - Illustration of the cover of A. Hitler's book, Mein Kampf, Werset: Kraków 1992, Polish edition.

(Source:www.google.com/searchq=mein +kampf+grafika $\&$ client $=$ firefox $\&$ tbm $=i$ sch $\&$ source $=i u \& i c t=)$

In 1926, he was recognized as the invariably binding program of the National Socialist German Workers' Party, which raised educational and upbringing issues. The program clearly emphasized

${ }^{4}$ Tomalska H., Wiedza o społeczeństwie, Wydawnictwo DIP, Warszawa 1998, s.46. that the curricula of all educational institutions should be adapted to the needs of practical life. It was emphasized that understanding of the idea of the state should be achieved from the very beginning of comprehension, and therefore from school.

Therefore, it was a postulate to strengthen the state's influence on education and the line of upbringing of the young generation. On February 24, 1920, the NSDAP Program (National Socialist German Workers' Party) was announced. In 1933-1945, it exercised totalitarian power in Germany.

NSDAP's rule was characterized by political terror, total surveillance, the liquidation of the opposition and the program of conquering Europe. The policy of conquest was accompanied by genocides carried out in conquered countries, especially in Poland, where several million citizens were murdered. The party leadership was recognized as a criminal organization in the Nuremberg trials, and the party itself banned the activities of the party on September $20,1945^{5}$ and in it pursuant to art. 21 a woman and a child were cared for by the state, and physical education of the broad masses of society was bound by applicable law. It was emphasized that the matter of motherhood and raising children, and the issue of social health are subject to state protection. Adolf Hitler's thoughts and assumptions expressed in "Mein Kampf" also concerned upbringing and school hygiene. Hitler clearly emphasized that there must be a balance in education between spiritual education and physical improvement. He criticized the educational system previously in force in Germany, writing "they sinned against the body as much as possible and it was thought that in unilateral education of the spirit a guarantee of the greatness of the nation was created." He believed that cowardice lies in physical weakness, which is the weakness of the individual, and ultimately of the state. Under the new program, the educational campaign began from the moment the child was born. Specially trained nurses and educated young mothers were to direct the child's upbringing so that a healthy child would grow out of him. The school was to "grow" healthy bodies in the foreground, and there would be more time in the programs for bodily improvement. The primary task of the school was to create children with a strong body, hardened toil and toil, possessing hardness and power that gives hope for the creation of a strong society. NSDAP formed special youth organizations such as Hitlerjugend ("Hitler's Youth") - a German NSDAP youth organization organized as a paramilitary model in 1922 as an addition to Assault Troops) for boys and Bund Deutscher Madel for girls (Association of German

\footnotetext{
${ }^{5}$ Hitler A., Mein Kampf, Wydawnictwo Werset, Kraków 1992, edycja polska, s. 280-284.
} 
Girls - women's section of the Nazi organization youth Hitlerjugend - it belonged to her girls from 13 to 17 years old $)^{6}$, in which camps, trips, hiking, marches, physical and combat exercises were compulsory. Special boarding schools were created to which individuals with strong and strong character and gushing physical health were directed. In addition, one of the school stages was the forced labor service of people, where, among others, sports, gymnastics and defense classes were held. The right to further education depended on the assessment of the labor camp and the results of the military service. Each student, for three semesters, had to take part in sport exercises, where they had to demonstrate physical fitness, combat character and devotion to German ideals. Successful completion of the 3 semesters was a pass to continue my studies and the transition to the fourth semester. In addition, universities held internal sporting competitions, district and academic championships for the title of the best individual and team sports center in Germany. The state was to conduct a health policy, look after mother and child, prohibit the work of minors, introduce compulsory physical education in schools and support sports clubs.

Hitler believed that everything that strengthens the body of the youth should be supported, especially boxing ${ }^{7}$. In his opinion, boxing educated militancy, rapid decision, steel perseverance and elasticity of the body. According to Hitler, a healthy boy had to learn how to endure punches. Physical fitness was very important for the founder of NSDAP, who believed that boys should deal with the development of physical strength for the nation in their free time and not be demoralized. According to the author of "Mein Kampf", the state was to take care of the physical development of young people, as well as arouse aggression, so that it would be ready to counter any possible threats. He saw military service as part of physical education and the process of education for patriotism.

In addition, every boy and girl was to leave school with a clear and final conviction of the necessity and sense of blood purity. He believed that this created the racial basis of German nationality and the necessary conditions for the future cultural development of Germany. After completing military service constituting the final termination of education, the young German was to receive a citizenship diploma and medical certificate, which in the event of confirmed health allowed him to marry. In his considerations in "Mein Kampf" he defined the educational ideal of the nation-

\footnotetext{
${ }^{6}$ Kitchen M., Trzecia Rzesza. Charyzma i wspólnota, Wydawnictwo Książka i Wiedza, Warszawa 2012, s. 219-221. ${ }^{7}$ Zand A., Szkoła i Wychowanie w Niemczech Hitlerowskich, Warszawa-Poznań 1939, odbitka z „Przeglądu socjologicznego", tom VII.
}

state - the embodiment of a male force and a woman capable of giving birth to men.

The reading "Mein Kampf" is struck by the thesis that the individual is the driving force of the nation and is its fullest, most important expression. Therefore, according to the leader of NSDAP, the individual should be harmoniously developed towards full adaptation to the principles of the state. This argument implies a postulate of political education, shaping the individual so that it harmonizes with the functions and rhythm of the state's operation. In the Third Reich (but also in other totalitarian states), special attention was paid to sport in the existence of a state that through its extreme centralism and extensive control apparatus became a tool for achieving many goals. An example of the instrumental treatment of sport by the Nazis was football ${ }^{8}$, which became an important and multifunctional tool of propaganda. In view of the special interest of European countries in this sport in the 1920s, it served the Nazis to build desirable relations with other countries, but also to create a peaceful image of the German state. For the Third Reich, with Hitler at the forefront, football was an instrument of ideological upbringing, deepening totalitarian control over the individual and the instrument of regime propaganda.

Adolf Hitler's state created a system whose method is based, inter alia, on developing, through physical education, the qualities of character necessary for victory and consolidation of the ideology of the state. In this way, a new educational ideal and a completely specific teaching method were created.

Instead of an educated, humanist personality, a real fighter. The educational ideal defined in this way fulfilled the role of Nazi education. Filling school, junior high and university years with continuous life for the individual and collective feat in sport, camp life or social work, as a result, had to tie a militant, athletic and fanatical young man with the state and the national-socialist party, which he wrote extensively in his work dr Andrzej Zand. Analyzing the whole educational system, methods and means, it is hard not to notice that the whole apparatus had repressive and bonus features. All manifestations of cultural life - science, press, art - served one purpose, developing the size of the Third Reich.

\section{Mussolini's fascism ("duce") and physical education}

In 1919, Italy also reached the totalitarian system. It should be mentioned here that in 1921 the program of the future fascist party was created. Executive and legislative functions were held in the

\footnotetext{
${ }^{8}$ Wyskok M., Instrumentalizacja pilki nożnej w państwie totalitarnym na przykladzie Trzeciej Rzeszy, Prace Naukowe Akademii im. Jana Długosza w Częstochowie, 2016, t. XV, nr 3, s. 1223
} 
Italian state by a Mussolini chief called duce. He combined various positions (head of the armed forces, prime minister, commander-in-chief, etc.) into one. It was Mussolini who was directly subject to the extensive police and control apparatus, but also counterintelligence and surveillance equipment.

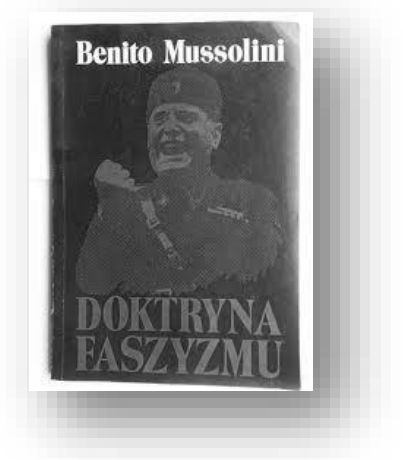

Fig. 3 - Book by Mussolini Benito, Doctrine of Fascism, Publisher Merkiusz Polski, 1939, reprint of the Lviv edition of 1935.

(Source:www.google.com/search?q=mussolini + grafika \& client $=$ firefoxb \&tbm=isch\&source $\mathrm{\&} i \mathrm{ct} x=1 \& f$ )

The powerful office "OVRA" (Volunteer Organization for Combating Antifascism) was established by the Italian fascist secret political police, created in 1927 on the instruction of Benito Mussolini, to combat political opponents and protect his regime. She conducted police, counterintelligence and political activity, using methods of repression, deportation and deportations to concentration camps. Its head was Arturo Bocchini, the former head of the Italian state police $)^{9}$, which cumulated the tasks of police, counterintelligence and national propaganda. All positions in the state were filled with members of the political support of the commander-the only party capable of exercising power from the National Fascist Party. Fascist policy was based on extensive state-funded activities financed from the budget. Public works were carried out, unemployment was eliminated, the army was enlarged, and a number of paramilitary youth organizations were founded. A state-owned, free health service, state education, and efficient police and court apparatus were introduced. All these activities gave the society a sense of security and stability. However, society was required to obey completely in its efforts to achieve the goals set by the state. The whole life of society was subordinated to totalitarian ideas. In order to indoctrinate the society, propaganda and political demonstrations and meetings with the commander's speech, military parades, and sports competitions were organized. A special organization Dopolavoro (After Work) organized employee holidays, created cultural and sports

${ }_{9}^{9}$ Mała Encyklopedia Powszechna PWN, Państwowe Wydawnictwo Naukowe, Warszawa 1974, s. 127. facilities, and social welfare facilities. As part of social policy, care for mother and child was initiated. In 1925, the First Mother and Child Care Organization in the world was established. Counseling centers for women and children, establishments for single mothers, eateries and nurseries were opened. Efforts were made to educate girls, future fascist mothers. A female academy was established in Umbria, where economy and physical training were taught. Kindergartens and Jordanian gardens were organized for young children. Fascist upbringing was also the goal of the children's organization "Balilla", where military-style troops were organized in special costumes. Specially made small rifles were used for military exercises. The fascists quickly understood the benefits of raising young people. How urgent this issue was for them can serve the example of the hymn of the fascist party, for which the song "youth" was chosen. The organizations of fascist youth aimed at inculcating Italian belligerence, determination, dynamism and shaping physical fitness. Huge emphasis was placed on physical culture and development of sports activities. In 1919, the first fascist organization for the education of youth "Student Avant-garde" was founded. In 1926, the National Balilla Work was founded. It was an organization of fascist youth in Italy, involving boys from 814 years old. The exercise was like scouting. After reaching the age of 14, the boys joined the organization "Avant-garde" or "front guard" - up to the age of 18 and received military training there. The name was adopted to commemorate the boy B., who in 1746 gave the slogan of the uprising against the Austrians in Genoa ${ }^{10}$. National Balilla Work organization was to shape children's physical fitness, a sense of discipline and political awareness. Semimilitary training with drill, gymnastics, parades and sports activities was also introduced. It should be clearly emphasized that the struggle, which is an inseparable aspect of fascist ideology, had not only practical tasks and goals, but also, and perhaps above all, educational goals. In Italy, the rich traditions of the Roman Empire were referred to. The main goal of fascist ideology was to create a unified state system with a powerful external and internal apparatus based on the army. The entire community was to constitute political, cultural and moral unity. The good of the country was the supreme good of the party and the good of the whole society. It should be emphasized, however, that this "perfect state" was ruled by the elites.

\section{Stalin \\ The state of the totalitarian regime of Joseph}

${ }^{10}$ Encyklopedia Powszechna, Wydawnictwo Gutenberga, Warszawa 1925 , s. 83. 
In totalitarian states, including the USSR (Union of Soviet Socialist Republics created on December 30, 1922 under the founding treaty of the USSR concluded by the Bolsheviks ruled jointly but formally independent: the Russian FSRR, the Ukrainian SSR, the Belarusian SSR and the Transcaucasian FSRR.

The USSR ceased to exist as a result of the conclusion of the Bialowieza agreement on December 8, 1991 and the declaration on the dissolution of the USSR adopted in Moscow by the Council of the Supreme Council of the USSR on December 26, 1991. $)^{11}$, based on the communist system, sport was nationalized for ideological purposes, and political reality, which it shaped this area of social life, it was subject to changes determined by border political events, as Piotr Godlewski wrote in his book "Performance sport in the process of ideological and social changes in Poland 1956-1989".

From 1917, using extremely totalitarian and dynamic propaganda, communist leaders were even worshiped. However, the cult of the individual. Józef Stalin - a Soviet politician of Georgian origin (December 6, 1878 - March 5, 1953), formally fulfilled the elective, term of office of the secretary general of the CPSU and its predecessors, and the prime minister of the USSR, and in fact the lifelong dictator of the Soviet Union, who had unlimited power ${ }^{12}$. He stuffed the society with the image of a beloved father of the nation, a defender of the poor and oppressed. His policy was extreme, he killed, built, destroyed and conquered en masse. He knew perfectly well that control over human minds would only be a lie - propaganda of the image proved to be indispensable. Sport very quickly became the weapon of communist ideology in the USSR. Soviet sport, the idea of competition, the principle of fair play have been distorted and completely subjected to the totalitarian regime. At the turn of the 1920s and 1930s, soul engineers saw in sport the instrument of raising a Stalinist man, homo sovieticus. Of course, it was supposed to be a "red" and joyful sport, which differed from that of false, paid, or capitalist. It is no wonder that its main feature was not competition, but participation developing the habit of collective action. That is how the myth of amateur sport arose, which he maintained over the next 50 years. However, it should be noted that its propagators divided into two doctrinal schools. The first, called conventionally hygienic, forced mass physical education in schools and many workplaces, and its supporters organized model gymnastic shows in order to in-

\footnotetext{
11 Pasko A., Społeczno-polityczne aspekty sportu w ZSRR krajach bloku socjalistycznego do 1989, Prace Naukowe Akademii im. Jana Długosza w Częstochowie. Kultura Fizyczna, Częstochowa 2012 (11) , 115-130.

${ }^{12}$ Mała Encyklopedia Powszechna PWN, Państwowe

Wydawnictwo Naukowe, Warszawa, 1974, s. 139.
}

crease learning and work efficiency. However, the mass sport was forge conscripts for the Red Army and NKVD, which nobody hid. The exercise program was dominated by athletics and paramilitary disciplines such as shooting and skydiving. Thanks to this, after the start of the war with the Third River, the political police formed from outstanding OMSBON athletes - the Motorized Special Purpose Brigade, which, according to Soviet sources, became famous for its numerous subversive actions. The second school, called proletarian culture, organized pseudo-sports festivals, during which thousands of participants creating live figures chanted the names of Lenin and Joseph Stalin. In fact, they were great performances intended for the participants themselves and one leader. Paradoxically, the sport discipline that reconciled both schools turned out to be bourgeois obsolescence, i.e. football.

The ruling party led by Stalin issued resolutions and resolutions regarding physical culture. The education system was reformed by education through work, subordination of the individual to the state and combining education with military training. In addition, sports training was to serve the defense of the country and increase the productivity of workers. In 1952, Soviet athletes took part for the first time in the Olympic Games, which initiated the sports competition of the socialist bloc countries with the West. Through victories over Western athletes, attempts were made to show the superiority of Soviet culture over the decadent Western world. The Soviet sport model was faithfully copied by the other Eastern Bloc countries ${ }^{13}$. The Soviet Union very skilfully used sport to create its global sphere of influence, especially since many politicians in the Third World saw in the successes at the ice rink or stadium arguments in favor of communist ideology and the Soviet way of life. The world did not know about the existence in the USSR of a multi-level system of control of athletes. The stars were not only supposed to win titles and medals, but correspond to the official stereotype of a harmoniously developed and ideologically right athlete. The price was also the decisive paralysis of sports institutions, because the players were to be sent only to win. In the event of a loss, everyone was responsible - from the player through the coach to the party decision-maker. The period of the greatest Stalinist terror did not bypass anyone - not only Soviet sport stars, but also sport trainers. Decisions about the fate of the players of their coaches were made at the highest level, as evidenced by documented records of meetings in the

\footnotetext{
${ }^{13}$ Pasko A., Społeczno-polityczne aspekty sportu w ZSRR i krajach bloku socjalistycznego do 1989, Prace Naukowe Akademil im. Jana Długosza w Częstochowie. Kultura Fizyczna, Częstochowa $2012(11), 115-130$.
} 
Kremlin. Individual success, under strict state control, was to bring benefits to the collective.

\section{Liberal democratic states}

How can you define a liberal democratic state? Generally speaking, it is a political organization of capitalist society that provides a minimum of democracy to society and a minimum of freedom for the individual, it develops the structure of civil (open) society. A characteristic feature of this country is, among others, a stable political system. The state is significantly involved in economic, cultural and social life by developing a system of social welfare, education and establishing rules of conduct and enforcing citizens to comply with these rules. The term "welfare state" is associated with this country. The state is expanding social assistance in the form of health, family and social insurance. It creates "equal opportunities" for all citizens. The features of a democratic state are, among others: pluralism, power exercised by a large social group, observance of human rights, freedom of speech, the most important value is man. Your welfare is e.g. Great Britain, Sweden. In England of the 17th century, education, and in it physical exercises played a significant role in the process of upbringing. It was John Lock (English philosopher, doctor, politician and economist, creator of the classical form of empiricism and liberalism) in "Thoughts on Upbringing" (1693) who wrote about a young "gentleman" who was well-educated and physically fit, which was to help young people achieve in life, goals also resulting from social obligation. It was individual and state interests that determined the then cultural and civilizational axiological horizon that shaped pedagogical thought, school programs, and physical education in them. In the second half of the 19th century, all social groups were educated in England. A characteristic phenomenon was sports games that were supposed to be an effective remedy for unruly young people. The reformer of education in England was T. Arnold, who introduced physical education to schools. In addition, extracurricular and extracurricular activities were characteristic for this period. An important moment was the introduction by Tomas Arnold in Rugby to the school curriculum of the original way of conducting physical education classes. It was supposed to be a modern educational method concerning mainly difficult youth. In England, unlike other countries, physical games and activities as well as inter-school sports competition had a prominent role in physical education classes. This way of conducting classes not only developed students' agility and motor skills, but also shaped their characters in such matters as independence, cooperation in a group, decision making, fight and competition. Gymnastics was introduced at the initiative of military circles. Herbert Spencer (English philosopher and sociologist) played a large role in this topic. In 1861, Herbert Spencer's work "On Mental, Moral and Physical Education" appeared, in which he drew attention to the utilitarian and military values of physical education, which in his opinion facilitate the success in life, the use of productive and commercial achievements. In Sweden, the Ling family had a great impact on the development of physical education and the educational system. Thanks to the Ling, physical education at that time stood at a high level in Sweden, and the system they created at a high level. One was the doctor Pehr Ling, the creator of the Swedish physical education system and the famous gym school. In 1813 he founded the Royal Central Gymnastic Institute in Stockholm. Courses for teachers (elementary and secondary schools) as well as instructors and people conducting therapeutic gymnastics were organized at the institute. Ling's main goal and assumption was to create models of physical education lessons that were supposed to provide students not only with physical fitness but also health, which made the Swedish educational system stand out from other countries. Ling's assumptions were largely influenced by the health problems of children and young people employed in the emerging industry. Pehr Ling saw values above all in courage, physical fitness and bravery, which was supposed to be a model for young generations. He taught fencing, swimming, wrestling and climbing. In addition, thanks to him, a general basis for four types of gymnastics (aesthetic, educational, therapeutic and military), lesson matrix, methodological basis and curriculum as well as gym plan were created in Sweden. Ling thought that planned physical education could not be arbitrary, but should be based on learning data. According to Ling, a close relationship between physical education and medicine was necessary. In turn, other members of the Ling family developed programs and methods of conducting physical classes in schools - introductory exercises, slopes, overhangs, balance exercises, marches, runs, etc. The correction of students' posture defects by appropriate selection of exercises was developed and introduced. The Ling family had a huge impact on the development of pedagogical and health goals achievable through properly conducted classes. The Lingas also made a significant contribution to the development of the first concepts of learning about movement, preparation and creation of tables for pedagogical courses. Swedish gymnastics has become a model for other countries also for another important reason - physical education for women was carried out taking into account their physiology ${ }^{14}$. These physical education

\footnotetext{
${ }^{14}$ Urniaż J., Gospodarka i polityka a szkolne wychowanie fizyczne w wybranych krajach europejskich i Polsce na
} 
systems from the beginning became a model for many countries until the outbreak of World War I and later. They were associated with the development of industry, which in the second half of the nineteenth century changed the economic face of states and created a new social group, workers. Along with global social transformations in the history of cultural history, among which politics and the economy were of fundamental importance in the state, modern school curricula were created, including physical education.

\section{Poland in liberal democracy}

In Poland, at the turn of history, there were also changes in education, in particular those regarding physical education, but they were not so dynamic. This state of affairs resulted from the way our country functioned in various historical periods - pre-partition times, partitions of Poland and the lack of it on world maps, all this had a significant impact on education in our country. For the first time, compulsory physical education, outdoor games and activities for health were introduced, only after the creation of the National Education Commission in 1773. However, the implementation of this educational program was not carried out properly and in accordance with the assumptions. The partitions that took place in the following years divided Poland into three parts, and thus the partitioning right was in force in each part. In the Prussian partition, education and physical education of Polish youth took place in accordance with the German school program. However, in the Russian and Austrian partitions at different times, the educational activity was sometimes influenced by Poles, but generally the partitioners wanted to de-nationalize Poles. The end of World War I also had an impact on education and physical education, which in leading European countries were subordinated to the politics and economy of individual countries. The revived Republic also introduced education reform (including physical education). The adopted program of physical education classes referred to the kalokagatii and program-methodological assumptions of Polish physical education theorists. The importance of physical culture increased after the introduction of the military dictatorship in 1926 by Józef Piłsudski due to the State Office of Physical Education and Wax Preparation, as well as the Central Institute of Physical Education. Both institutions were responsible for all matters related to physical education and physical culture. At this point, therefore, I must emphasize that it was national and state matters that determined the value of physical education classes. In Poland, during Stalinism, as well as over the next few decades, sport de-

przestrzeni dziejów, Prace Naukowe Akademii im. Jana Długosza w Częstochowie, 2017, t. XVI, nr 3, s. 11-28. veloped within the strict political reality in which the Marxist-Leninist party played a leading role ${ }^{15}$.

\section{Purpose}

The party and government authorities adopted the doctrine that sport is an important element of internal and external ideological struggle. All sporting successes created a positive grounding for the ideological propaganda of success. The ideological impact in this sphere of life and education served the indoctrination of children and young people in order to demonstrate the superiority of communist upbringing. For the purposes of propaganda, the myth of a sports hero was created, human perfection unattainable in the capitalist system. One of the components of the totalitarian system of the Polish People's Republic was propaganda by sport, among others by the sports press. After 1945, Poland found itself in the sphere of influence of the Soviet Union. The ideology imposed on Poland covered all areas of social life, including education. Access to education, work, health care, culture, including physical culture and sport, was promoted and given high rank in society. After all, a healthy and physically fit citizen was needed to work, defend the country and the system. I will not describe what cultural changes have occurred, but I must mention that all children in the country were covered by education. The duty of physical education covered all children and youth. There was a big development of the school sports base. New colleges of physical education were established. Professionals were trained to conduct classes in physical culture. There were extracurricular activities and sports clubs for young people interested in sport. Schools introduced corrective classes, gymnastics, athletics and team games. In addition, sport competitions were organized at various levels. At that time, sport was to be a means of raising the health condition of Polish society, it was to serve social, ideological and educational tasks. Until 1989, physical culture and sport were at the service of the policy of a totalitarian state, and the entire management system was subordinated to the monoparty political leadership of the PZPR. After 1989, with the collapse of the communist authorities in Poland and the totalitarian regime, a period of transformation began, which also covered physical culture. Along with the socio-economic changes taking place in our country, new program and methodological concepts of physical education were also introduced. After the fall of communism of the Third Republic of Poland, it began to integrate with the free world in an economic, civilizational and cultural context. There have been radical changes in education that we are observing to this day. Democratic education

\footnotetext{
15 Godlewski P., Sport wyczynowy w procesie przemian ideologicznych i społecznych w Polsce 1956-1989, Wydawnictwo Athenae Gedanenses, Gdańsk 2015, s. 93-95.
} 
should be used to build a critical attitude, which in a constructive way will enable the creation of such dispositions for action that will allow for real and lasting changes. It cannot be instrumental or adaptive, but an individual functioning in such a society is not alienated from the community and moral obligations. In the works of such thinkers as, e.g. Celestyn Freinet (French pedagogue, creator of the "French modern school", theoretician and educational practices, creator of an original system of work with children, based on partnership, self-governing procedures and institutions and stimulation of selfeducation, a researcher of the world of children), or Janusz Korczak actually Henryk Goldszmit, (died in August 1942 in Treblinka - a Polish-Jewish doctor, educator, writer, publicist and social activist) there were reflections on the idea of education for democracy. Barbara Woynarowska ('Health Education. Academic Handbook) emphasizes that she enables the individual to obtain competences to protect and improve one's own health and that of other people, is the foundation for the school's prevention program ${ }^{16}$. According to B. Woynarowska, this process in which people learn to care for health is a didactic and educational process in which young people learn to live to preserve and improve their own and others' health, but also to live in harmony with other people and environment. Thanks to health education, children and young people have information that will allow them to actively participate in treatment, rehabilitation and reduction of their negative effects in the event of illness or disability. The basic issues in health education include, among others: hygiene and body care along with self-control, health and antihealth behavior, care for health, healthy lifestyle for increasing the potential of your health, taking actions to protect against threats, eliminating healththreatening behaviors and others. youth

Health and safety goals of children and

In contrast to traditional health programs focused mainly on physical health, it is now believed that health education at school should take into account many different goals, which is associated with undertaking many activities in the field of teaching, education and prevention ${ }^{17}$. In recent years, many changes have been made to the concept and implementation of health education based on the adoption of a holistic, holistic health model. This model includes physical, mental, emotional, social, spiritual and sexual health. The most important features of modern education of children and adolescents are: taking into account all the "types" of health I wrote

\footnotetext{
${ }^{16}$ Woynarowska B., Edukacja zdrowotna, Wydawnictwo Naukowe PWN, Warszawa 2018, s.15-18.

${ }^{17}$ Lock J., Myśli o wychowaniu, Wydawnictwo akademickie „Żak”, Warszawa 2004, s. 55-56.
}

about above, also practicing health-promoting behaviors, participation in state-funded programs. In the new general education basis introduced, the status of health education has changed, where physical education plays a leading role ${ }^{18}$. The adopted solution is in line with one of the models recommended by the World Health Organization. Content related to health was included in many subjects, separating them from physical education. At individual educational stages, the distribution of messages and hours allocated to education and physical education is different. It is also extremely important for teachers to model health attitudes and behavior in accordance with the core curriculum using various persuasion techniques. Currently, a democratic approach is being implemented in Poland and other European Union countries that allows young people to make their own choices. In addition, the dissemination of new information technologies makes the classes more attractive, which is associated with greater interest in this topic.

\section{school}

Implementation of health education at

The position of the Minister of National Education in cooperation with the Minister of Health and the Minister of Sport clearly defines the tasks of the school regarding, among others, satisfying the nutritional needs of children and adolescents, ensuring the specific nutritional needs of children with chronic diseases, implementing proper nutrition programs, enabling school staff to participate in various forms of improvement professional in nutrition and others. In accordance with applicable regulations, a school nurse (hygienist) supervises students in every school. It conducts screening tests and health balances, fluoridation of teeth in grades I-VI of primary schools, provides emergency assistance in emergency cases, conducts various talks and preventive services at the school premises in accordance with the Act on healthcare services financed from public funds. (Legal basis Regulation of the Minister of Health of March 21, 2007 amending the regulation on the scope and organization of preventive health care for children and youth, Journal of Laws 2007 No. 56 item 379, as amended). Physical education in schools is carried out hourly and methodically in different ways, depending on the level of education. The primary goal of physical education is considered to be improving both the body and psychomotor functions of the pupil, as well as shaping in him such a system of knowledge, skills and habits as well as attitudes towards physical culture, which in practice will be manifested in the pursuit and action to maintain high fitness throughout life physical and health. During physical education lessons in accordance with the curricu-

\footnotetext{
${ }^{18}$ Drabik J., Aktywność fizyczna w edukacji zdrowotnej społeczeństwa, Wyd. AWF, Gdańsk, s.19-21.
} 
lum assumptions, we should shape the positive attitude of the student towards the physical fitness of his body. In the current Polish education system, the main purpose of physical education should be to improve the body and psychomotor functions of the pupil, as well as to shape his system of knowledge, skills and habits as well as attitudes towards physical culture, which in practice will be manifested in the quest to maintain lifelong high physical fitness and health. Shaping a positive attitude towards the physical fitness of your own body, convince the student about the value of physical fitness of the body and focus on improving their own physical fitness in the field of classes, and then, using appropriate forms and methods, focus on independent action in this field, i.e. for self-realization. Education in Poland is experiencing economic and program problems. These problems also apply to physical education, which is of little importance in the education of a Polish student. The changes taking place in contemporary, developed societies, including Poland, carry a whole range of health threats. The most important is the popularization of a sedentary lifestyle, from early childhood (computers, television, telephones, tablets, etc.) to old age. The lack of regular physical activity, to which man has been phylogenetically adapted, along with adverse health behaviors (e.g. excessive and caloric supply of food), results in an increase in overweight and obesity and a whole range of civilization diseases. Systematic physical activity plays an important role in preventing these adverse phenomena. In the face of the above threats, it is reasonable that a high level of physical and health culture should be an integral part of our daily lives at all ages. On the basis of existing theoretical knowledge and empirical research, pedagogues, doctors and representatives of physical culture sciences are convinced that showing and emphasizing the valuable values of physical and health culture is an opportunity for them to become the chief element of a healthy lifestyle of the whole society.

\section{Conclusion}

A certain difficulty of my work is the asymmetry of issues between physical culture and health education in democratic and totalitarian systems in favor of the democratic system. In order to obtain the necessary information, I reached for rich materials and studies on totalitarian systems to get a picture of the subject. In conclusion, I want to emphasize that always, in every country over the centuries, regardless of the political system of exercising power - politics and economy functioned in mutual relation with education, upbringing, including models of physical culture. The foundation of physical culture in each country is the school physical education system. The task of physical education methodology is to create a rational, structural model of putting the theory into practice. Physical culture as a social phe- nomenon stands out from others in that its influences concern man as a whole, concern both the body and its needs as well as personality. The most useful for the theory of education in physical culture is the definition of Maciej Demel (Polish pedagogue, doctor, professor of physical culture sciences, specialist in the theory of physical education and health pedagogy, creator of the Polish school of health education of the modern concept of physical education), according to which: "Physical culture includes all those values that are associated with the physical form and physical functioning of man, both in his own subjective perception and in the socially objectified image. These values - generally speaking relate to health, physique and posture, immunity, endurance, fitness, and beauty. Similarly to other cultural values, they have a dynamic character, shape human views and attitudes, so they are part of the worldview and customs ${ }^{19}$. The rapid development of modern technical and urban civilization brings alongside convenience and pleasure, as well as a reduction in physical effort, also negative transformations. The most dangerous of them, apart from noise, nervous lifestyle, lack of space, harmful radiation, etc. is the progressive elimination of physical effort from the lives of human individuals. In Poland, it is a misunderstanding today to deprive children of the possibility of physical development in schools due to the risk of lowering the average grade by a possible worse grade in sports activities.

\section{References:}

1. Demel M., Pedagogika zdrowia, WSiP, Warszawa 1980.

2. Drabik J., Aktywność fizyczna w edukacji zdrowotnej społeczeństwa, Wyd. AWF, Gdańsk.

3. Encyklopedia Powszechna, Wydawnictwo Gutenberga, 1925.

4. Godlewski P., Sport wyczynowy w procesie przemian ideologicznych i społecznych $\mathrm{w}$ Polsce 1956-1989, Wydawnictwo Athenae Gedanenses, Gdańsk 2015.

5. Hitler A., Mein Kampf, Wydawnictwo Werset, Kraków 1992, edycja polska

6. Kitchen M., Trzecia Rzesza. Charyzma i wspólnota, Wydawnictwo Książka i Wiedza, Warszawa 2012, rozdział Edukacja.

7. Lock J., Myśli o wychowaniu, Wydawnictwo akademickie „Żak”, Warszawa 2003.

8. Mała Encyklopedia Powszechna PWN, Państwowe Wydawnictwo Naukowe, Warszawa, 1974.

9. Marrou H.I, Historia wychowania w Starożytności, Warszawa 1969.

\footnotetext{
${ }^{19}$ Demel Maciej, Pedagogika zdrowia, WSiP, Warszawa 1980, s. 67-69.
} 
10.Mussolini B., Doktryna Faszyzmu, Wydawnictwo Merkiusz Polski, 1939, reprint wydania lwowskiego z 1935.

11.Okoń W., Nowy słownik pedagogiczny, Wydawnictwo Akademickie Żak, Warszawa 2017.

12.Ordyłowski M., Historia kultury fizycznej, Starożytność-Oświecenie, Akademia Wychowania Fizycznego we Wrocławiu, Wrocław 1997.

13. Overy R., Dyktatorzy. Hitler i Stalin, Wydawnictwo Dolnośląskie, Wrocław 2009.

14.Pasko A., Społeczno-polityczne aspekty sportu w ZSRR i krajach bloku socjalistycznego do 1989 r., Prace Naukowe Akademii im. Jana Długosza w Częstochowie, Częstochowa 2011.

15.Tomalska H., Wiedza o społeczeństwie, Wydawnictwo DIP, Warszawa 1998.

16.Urniaż J., Gospodarka i polityka a szkolne wychowanie fizyczne w wybranych krajach europejskich i Polsce na przestrzeni dziejów, Prace Naukowe Akademii im. Jana Długosza w Częstochowie, Częstochowa 2017.

17. Woynarowska B., Edukacja zdrowotna, Wydawnictwo Naukowe PWN, Warszawa 2018.

18. Wyskok M., Instrumentalizacja piłki nożnej w państwie totalitarnym na przykładzie Trzeciej Rzeszy, Prace Naukowe Akademii im. Jana Długosza w Częstochowie, Częstochowa 2016.
19.Zand A., Szkoła i wychowanie w Niemczech Hitlerowskich, „Przeglądu socjologicznego”, tom VII, Warszawa-Poznań 1939.

\section{Legal acts}

Rozporządzenie Ministra Zdrowia z dnia 21 marca 2007 r. zmieniające rozporządzenie w sprawie zakresu i organizacji profilaktycznej opieki zdrowotnej nad dziećmi i młodzieżą Dz.U. 2007 nr 56 poz. 379 z późn. zmianami.

\section{Internet sources}

1. https://pl.wikipedia.org/wiki/Adolf_Hitler

2. https://pl.wikipedia.org/wiki/Benito_Mussolini

3. https://pl.wikipedia.org/wiki/Maciej_Demel

4. https://www.google.com/search?client=firef ox-b\&ei=oAj4W8HVNMOssgG1-

YPAAg\&q=paideia+grafika

5. https://www.google.com/search?q=mein+ka $\mathrm{mpf}+$ grafika\&client=firefox-b\&tbm isch\&source $=$ iu\&ictx

6. https://www.google.com/search?q=mussoli ni+grafika\&client=firefox -

$\mathrm{b} \& \mathrm{tbm}=\mathrm{isch} \&$ source $=\mathrm{iu} \& \mathrm{ict} \mathrm{x}=1 \& \mathrm{f}$

7. https://www.google.com/search?client=firefo x-b\&ei=yAn4W_juA4T8sQGZxI3QAQ\&q

$=$ stalin\&oq $=$ stalin $\&$.

\section{*Оглядова стаття}

